\title{
IMPLEMENTASI KEBIJAKAN LAYANAN SECARA ELEKTRONIK PENGADAAN KENDARAAN DINAS PEMERINTAH PROVINSI JAWA BARAT
}

\author{
Yusa Djuyandi \\ Marketing Communication Department, Faculty of Economic and Communication, BINUS University \\ Jln. K.H. Syahdan No. 9, Palmerah, Jakarta Barat 11480 \\ yusa@binus.ac.id
}

\begin{abstract}
Electronic Procurement Service (LPSE) is a policy in the procurement of goods and services with internet-based, which facilitates a transparent auction. West Java was chosen as one of the 5 LPSE Center and expected to create transparency and accountability in government management. The purpose of this study is to describe and analyze the LPSE policy implementation, particularly in the procurement of official vehicles in West Java Provincial Government. The research was conducted through observation and interview techniques. Data consisted of primary and secondary data, therefore this research design used qualitative methods. The theory used in this study was the theory of policy implementation. Based on the research, it is known that the policy implementation of LPSE, particularly in the procurement of official vehicles in West Java Provincial Government, is not only able to minimize the corruption potential, but also able to provide a positive impact on the financial condition of local governments. This research conclusion is LPSE policy implementation running well.
\end{abstract}

Keywords: transparency, accountability, corruption, policy implementation

\begin{abstract}
ABSTRAK
Layanan Pengadaan Secara Elektronik (LPSE) merupakan kebijakan pengadaan barang dan jasa berbasis Internet yang memfasilitasi lelang secara transparan demi menghindari terjadinya potensi korupsi. Provinsi Jawa Barat dipilih sebagai salah satu satu dari 5 Pusat LPSE oleh Bappenas diharapkan mampu menciptakan transparansi dan akuntabilitas dalam manajemen pemerintahan. Tujuan penelitian ini adalah untuk mendeskripsikan dan menganalisis implementasi kebijakan LPSE dalam pengadaan kendaraan dinas di Pemerintah Provinsi Jawa Barat. Penelitian ini dilakukan melalui teknik observasi dan wawancara. Data yang dikumpulan terdiri dari data primer serta data sekunder di lapangan. Untuk itu desain penelitian ini menggunakan metode kualitatif. Adapun teori yang digunakan dalam penelitian ini adalah teori implementasi kebijakan. Berdasarkan hasil penelitian diketahui bahwa implementasi kebijakan LPSE dalam pengadaan kendaraan dinas selain mampu meminimalisir terjadinya potensi korupsi anggaran, juga mampu memberikan dampak yang positif bagi kondisi keuangan daerah. Kesimpulan penelitian ini adalah implementasi kebijakan LPSE dalam pengadaan kendaraan dinas Pemerintah Provinsi Jawa Barat berjalan dengan baik.
\end{abstract}

Kata kunci: transparansi, akuntabilitas, korupsi, implementasi kebijakan 


\section{PENDAHULUAN}

Di tengah kondisi ekonomi bangsa yang masih belum sepenuhnya stabil dan derasnya tuntutan bagi terwujudnya pemerintahan yang bersih, peduli, dan profesional, masyarakat semakin kritis terhadap berbagai langkah dan kebijakan yang diambil oleh pemerintah. Tidak terkecuali dalam hal pengadaan barang; pemerintah dituntut untuk melakukan penghematan anggaran. Akan tetapi, berdasarkan pengamatan penelitian terhadap fenomena pengadaan barang untuk operasional kegiatan pemerintah saat ini justru sebaliknya. Fenomena tersebut dapat berpotensi menimbulkan pemborosan yang luar biasa, belum lagi jika berbicara mengenai transparansi terkait dengan mata anggaran pengadaannya.

Indonesia setelah memasuki tahun 1998 mencoba melakukan sebuah reformasi politik yang bersifat mendasar di bidang penyelenggaraan negara. Tujuan utamanya adalah membangun Indonesia yang lebih kuat, adil, dan sejahtera. Salah satu agenda utama reformasi adalah untuk mewujudkan pemerintah yang bersih (clean government) dan tata pemerintahan yang baik (good governance). Sejalan dengan itu, pemerintah melaksanakan demokratisasi politik dan desentralisasi sistem penyelenggaraan negara, melakukan reformasi birokrasi, dan peningkatan upaya pemberatasan korupsi melalui legislasi dan tindakan-tindakan 'ad hoc' seperti pembentukan Komite Pemberantasan Korupsi (KPK) pada 2002.

Persoalan transparansi anggaran dalam pengadaan barang yang mempunyai indikasi perilaku korupsi merupakan permasalahan yang menjadi fokus utama untuk segera diselesaikan. Korupsi diketahui mempunyai akibat buruk pada pertumbuhan ekonomi dan kemakmuran rakyat suatu negara. Meskipun investasi meningkat, jika di sana terjadi sumber korupsi, produktivitas akan rendah karena terjadi kesalahan alokasi investasi sektor ekonomi. Korupsi merugikan pelayanan publik karena buruknya kualitas barang dan jasa yang dihasilkan dari proyek-proyek pengadaan dan/atau tidak sesuainya antara nilai barang sesungguhnya dengan niai barang yang diajukan (mark up). Korupsi juga sering menimbulkan ketidakstabilan politik yang menyebabkan pemerintahan tidak berjalan efektif.

Meskipun Corruption Perseption Index (CPI) Indonesia pada 2011 mengalami peningkatan nilai sebesar 0,2 (pada $2010=2.8$; pada $2011=3$ ), tingkat korupsi di Indonesia masih memprihatinkan. Berdasarkan hasil survey Corruption Perseption Index (CPI) pada 2011 yang dilakukan oleh Transparency International (TI), dari 182 negara yang disurvei, Indonesia menduduki peringkat 100 dengan skor 3 bersama dengan Argentina, Benin, Burkina Faso, Madagaskar, Djibouti, Malawi, Meksiko, Sao Tome and Principe, Suriname, dan Tanzania. Menurut Transparency International, negara dengan skor 0 dianggap sebagai yang terkorup, sedangkan angka 10 adalah yang paling bersih (Traparency International, 2011). Berikut hasil survei CPI yang disampaikan dalam bentuk tabel.

Tabel 1 Peringkat Negara Berdasarkan Corruption Perceptions Index

\begin{tabular}{|c|c|c|}
\hline Rank & Country & Score \\
\hline 100 & Argentina & 3 \\
\hline 100 & Benin & 3 \\
\hline 100 & Burkina Faso & 3 \\
\hline 100 & Djibouti & 3 \\
\hline 100 & Gabon & 3 \\
\hline 100 & Indonesia & 3 \\
\hline 100 & Madagascar & 3 \\
\hline 100 & Malawi & 3 \\
\hline 100 & Mexico & 3 \\
\hline 100 & Sao Tome and Principe & 3 \\
\hline 100 & Suriname & 3 \\
\hline 100 & Tanzania & 3 \\
\hline
\end{tabular}


Berbagai upaya pemerintah Indonesia untuk memerangi korupsi memang sedang gencar dilakukan, khususnya oleh KPK, tetapi proses pemberantasan korupsi masih jauh dari harapan. Salah satu ruang tempat terjadinya korupsi di lingkungan birokrasi pemerintahan selama ini ialah dalam proses pengadaan barang dan jasa. Setiap tahun proses pengadaan barang dan jasa besarnya diperkirakan mencapai Rp 35 triliun atau sekitar 3,0 persen dari nilai anggaran belanja negara. Kebocoran tersebut menyebar ke daerah-daerah karena sekitar 65 persen belanja negara dalam APBN ke daerah melalui dana perimbangan, dana dekosentrasi, dan dana tugas perbantuan. Itu belum termasuk kebocoran dalam pengadaan barang dan jasa pemerintah daerah yang dananya bukan bersumber dari APBN (LGSP, 2011).

Praktik korupsi dalam pengadaan barang tidak hanya terjadi manakala muncul ketidaksesuaian fungsi dan manfaat kendaraan bagi pemerintah, tetapi praktik korupsi juga terjadi manakala harga barang dalam proses pengadaannya ternyata banyak yang berpotensi di-mark up. Sejumlah barang seperti kendaraan dinas, misalnya, dipatok melebihi standar biaya yang diatur Peraturan Menteri Keuangan (PMK) Nomor 100 tahun 2010 tentang Standar Biaya Umum. Pengadaan barang berupa kendaraan dinas memang dibutuhkan oleh sebagian besar instansi pemerintahan, termasuk pemerintah daerah, tetapi dalam proses pengadaannya harus transparan dan sesuai dengan yang dibutuhkan pemerintah.

Bagi Indonesia kegagalan dalam memberantas korupsi secara signifikan akan sangat mempersulit upaya pengurangan penduduk miskin, menurunkan angka pengangguran, meningkatkan penyediaan kebutuhan dasar masyarakat yaitu pendidikan, pelayanan kesehatan dan peningkatan akses terhadap air bersih dan sanitasi bagi penduduk berpenghasilan menengah ke bawah. Menurut Transparency International (2011): "corruption hits poor people hardest - with devastating consequences". Sejumlah data dari beberapa negara Asia menunjukkan bahwa negara dengan peringkat korupsi lebih rendah, lebih berhasil dalam upaya penurunanan penduduk miskin. Dengan menggunakan ukuran pengeluaran kurang dari 2 dolar AS sehari (kemiskinan absolut), Laos berhasil mengurangi kemiskinan dari 22,8 persen pada 2004 menjadi 12,2 persen pada 2008. Untuk periode yang sama, di Kamboja penduduk miskin turun dari 19 persen menjadi 8,7 persen, di Vietnam dari 7,8 persen menjadi 3 persen, dan di China dari 10,3 persen menjadi 6,1 persen. Penurunan di Indonesia adalah yang paling lambat, dari 7,4 persen menjadi 5,9 persen (Kompas, 2009).

Kasus korupsi dalam hal pengadaan kendaraan tidak hanya terjadi di lingkungan pemerintah pusat, tetapi juga terjadi di lingkungan pemerintah daerah. Proyek pengadaan barang selalu dapat menimbulkan celah korupsi yang melibatkan pihak panitia pengadaan dan peserta pengadaan. Di Jawa Barat praktik korupsi dalam hal pengadaan kendaraan pernah terjadi ketika kepemimpinan Gubernur Danny Setiawan, yang pada akhirnya membuat mantan Gubernur Jawa Barat ini dijatuhi hukuman oleh KPK (Tempo, 2009).

Perilaku korupsi dapat muncul karena ada niat dan kesempatan yang diperoleh, proses pengadaan barang yang tidak terbuka, dan cenderung lebih banyak dilakukan melalui tatap muka langsung. Perilaku tersebut telah memberikan kesempatan kepada dua pihak yang akan bertransaksi untuk melakukan negosiasi harga dengan cara yang tidak wajar. Pada umumnya, mereka yang memenangi tender pengadaan barang dan jasa tidak hanya disebabkan karena jumlah nominal harga barang yang bersaing dengan para kompetitor lainnya, tetapi juga disebabkan karena kedekatan dan imbalan yang diberikan oleh peserta tender (vendor) kepada panitia pelaksana pengadaan.

Munculnya desakan masyarakat agar terwujudnya perbaikan kualitas pelayanan pengadaan barang yang lebih transparan dapat meminimalkan dan menutup celah terjadinya praktik korupsi. Hal itu telah memunculkan sebuah kebijakan baru dalam hal pengadaan barang dan jasa. Layanan Pengadaan Secara Elektronik (LPSE) merupakan sistem pengadaan barang dan jasa secara elektronik menggunakan teknologi informasi dan komunikasi berbasis Internet (e-procurement) yang memfasilitasi lelang secara cepat, transparan, mudah, akurat dan terlindungi. Dalam penggunaan $e$ - 
procurement, proses lelang yang dilakukan secara elektronik adalah: pengumuman lelang oleh Panitia; pengunggahan dokumen lelang oleh Panitia; pengunduhan dokumen lelang oleh Panitia; penjelasan lelang; pemasukan dokumen penawaran oleh Penyedia; pembukaan dokumen penawaran oleh Panitia; pengumuman pemenang lelang; dan sanggahan kepada PPK. Dengan LPSE diharapkan tuntutan dan harapan masyarakat dalam mendambakan sebuah pemerintahan yang bersih, transparan, dan accountable dapat terwujud.

LPSE dibentuk di berbagai instansi dan pemerintah daerah untuk melayani Unit Layanan Pengadaan (ULP) atau Panitia/Pokja ULP pengadaan yang akan melaksanakan pengadaan barang dan jasa secara elektronik. Seluruh ULP dan Panitia/Pokja ULP pengadaan, diharuskan menggunakan fasilitas LPSE yang terdekat dengan tempat kedudukannya. Penyelenggaraan pengadaan barang dan jasa pemerintah secara elektronik mempunyai landasan hukum yang kuat yang menjamin keabsahaannya. Peraturan perundang-undang tersebut antara lain: (1) Keputusan Presiden Nomor 80 Tahun 2003 tentang Pedoman Pelaksanaan Pengadaan Barang dan Jasa Publik; (2) Instruksi Presiden Nomor 5 Tahun 2003 tentang Paket Kebijakan Ekonomi Menjelang dan Sesudah Berakhirnya Program Kerjasama dengan International Monetary Fund (IMF); (3) Instruksi Presiden Nomor 5 Tahun 2004 tentang Percepatan Pemberantasan Korupsi; (4) Peraturan Presiden Nomor 8 Tahun 2006 tentang Perubahan Keempat atas Keputusan Presiden Nomor 8 Tahun 2003 (tentang Pedoman Pelaksanaan Pengadaan Barang dan Jasa Pemerintah); (5) Undang Undang No. 11 Tahun 2008 Tentang Informasi dan Transaksi Elektronik; (6) Peraturan Presiden Nomor 54 Tahun 2010 tentang Pengadaan Barang/Jasa Pemerintah, Pasal 106.

Pada dasarnya lelang pengadaan barang/jasa secara elektronik tidak berbeda dengan penyelenggaraan lelang secara manual yang mengacu kepada Keputusan Presiden RI No. 80 Tahun 2003 tentang Pedoman pelaksanaan Pengadaan barang/jasa Pemerintah beserta aturan-aturan perubahannya, terakhir sebagaimana yang diatur dalam Peraturan Presiden No. 8 Tahun 2006. Namun kebijakan yang diterapkan dengan sistem ini diyakini lebih dapat meningkatkan dan menjamin terjadinya efisiensi, efektivitas, transparansi, dan akuntabilitas dalam pembelanjaan uang negara. Proses pengadaan barang dan jasa pemerintah secara elektronik dapat lebih menjamin tersedianya informasi, kesempatan usaha, serta mendorong terjadinya persaingan yang sehat, dan terwujudnya keadilan (non discriminative) bagi seluruh pelaku usaha yang bergerak di bidang pengadaan barang dan jasa pemerintah. Berbagai proses yang menimbulkan potensi terjadinya lobi, mark up anggaran, dan proses suap kepada panitia pengadaan lelang semaksimal mungkin ruang lingkupnya dipersempit. Hal ini terlihat dari proses tatap muka dengan rekanan hanya pada saat penandatangan kontrak.

LPSE bersifat online dan terbuka sehingga siapa pun bisa mengawasi dan melihat langsung proses pelelangan yang dilaksanakan. Penyedia dapat mengetahui langsung peringkat penawaran. Panitia juga tidak bisa serta merta mencari-cari kesalahan rekanan tanpa melihat fakta dan bukti yang ada sehingga penyedia tidak perlu khawatir atas transparansi dan akuntabilitas dari proses pelelangan secara elektronik ini.

Provinsi Jawa Barat dipilih oleh Bappenas menjadi salah satu satu dari 5 Pusat Layanan Pengadaan Barang dan Jasa Pemerintah Secara Elektronik berbasis Internet (e-government procurement) Regional. Dengan dipilihnya Provinsi Jawa Barat, maka secara faktual Provinsi Jawa Barat telah memasuki era baru, yaitu era e-government atau layanan pemerintah secara elektronik yang memfasilitasi tata pemerintahan yang baik (good governance) melalui peningkatan transparansi dan akuntabilitas dalam manajemen pemerintahan, serta lebih membuka kesempatan bagi publik untuk berpartisipasi aktif dalam penentuan kebijakan dan proses pengambilan keputusan pemerintah.

Berdasarkan pada fenomena yang telah diuraikan, penelitian diberi judul: Implementasi Kebijakan Layanan Pengadaan Secara Elektronik (LPSE) dalam Pengadaan Kendaraan Dinas di Pemerintah Provinsi Jawa Barat. Dari latar belakang yang telah diuraikan, rumusan masalah penelitian ini adalah bagaimana Implementasi Kebijakan Layanan Pengadaan Secara Elektronik (LPSE) dalam 
Pengadaan Kendaraan Dinas di Pemerintah Provinsi Jawa Barat? Sedangkan tujuan dari penelitian ini adalah untuk mendeskripsikan dan menganalisis implementasi kebijakan Layanan Pengadaan Secara Elektronik (LPSE) dalam pengadaan kendaraan dinas di Pemerintah Provinsi Jawa Barat. Manfaat atau kegunaan hasil penelitian dapat diklasifikasikan menjadi manfaat teoretis dan manfaat praktis. Secara teoretis, penelitian ini diharapkan dapat bermanfaat bagi pengembangan ilmu pengetahuan, khususnya yang terkait dengan ilmu kebijakan publik. Secara praktis, penelitian bermanfaat sebagai sarana belajar untuk mengintegrasikan pengetahuan dan kemampuan dalam implementasi kebijakan publik.

\section{Landasan Teori}

Implementasi kebijakan merupakan tahap yang krusial dalam proses kebijakan publik. Suatu kebijakan atau program harus diimplementasikan agar mempunyai dampak atau tujuan yang diinginkan. Van Meter dan Van Horn (2004:447-448) mendefinisikan implementasi kebijakan publik sebagai "Policy implementation encompasses those actions by public or private individuals (or groups) that are directed at the achievement of objectives set forth in prior policy decisions." Dari definisi, dapat diketahui bahwa tahap implementasi kebijakan tidak akan dimulai sebelum tujuantujuan dan sasaran-sasaran ditetapkan atau diidentifikasikan oleh keputusan-keputusan kebijakan. Dengan demikian, tahap implementasi kebijakan terjadi hanya setelah undang-undang ditetapkan dan dana disediakan untuk membiayai implementasi kebijakan tersebut.

Studi implementasi kebijakan menurut Winarno (2005) menambahkan suatu dimensi baru pada analisis kebijakan sehingga memberikan suatu pemahaman baru tentang suatu sistem yang berhasil atau gagal dalam menerjemahkan tujuan-tujuan kebijakan secara umum ke dalam pelayanan publik yang nyata dan bermakna bagi para peminat politik dan pembuat keputusan. Pendapat yang dikemukakan oleh Winarno memberikan sebuah pesan kepada seluruh pembuat kebijakan (keputusan) bahwa proses implementasi kebijakan tidak dapat diabaikan oleh para pembuat kebijakan dan analis kebijakan. Adanya pengabaian akan menimbulkan dampak negatif terhadap program-program yang telah ditetapkan.

Implementasi kebijakan merupakan tahap yang bersifat praktis dan berbeda dengan formulasi kebijakan sebagai tahap yang bersifat teoretis. Anderson (2010:25) mengemukakan: "Policy implementation is the application by government's administrative machinery to the problems." Kemudian Edwards III (2008:1) menjelaskan: "policy implementation,... is the stage of policy making between establishment of a policy... and the consequences of the policy for the people whom it affects."

Berdasarkan pandangan yang dikemukakan oleh Anderson dan Edward III, terlihat dua hal penting yang terdapat dalam implementasi kebijakan, yaitu adanya upaya untuk memecahkan masalah, dan implementasi kebijakan memiliki dampak terhadap masyarakat. Akan tetapi, pada dasarnya implementasi adalah sebuah proses suatu kebijakan yang telah ditetapkan kemudian dijalankan. Hal ini diperkuat oleh pendapat Buse, et.al. (2005): "Implementation is the process of turning policy into practice. However, it is common to observe a 'gap' between what was planned and what actually occurred as a result of a policy."

Hampir tidak ada pandangan yang begitu berbeda ketika menelusuri definisi dari sebuah implementasi kebijakan. Tachjan (2006) juga mengungkapan bahwa implementasi kebijakan publik merupakan proses pelaksanaan kebijakan yang dilakukan setelah kebijakan ditetapkan dan disetujui. Kegiatan ini terletak di antara perumusan kebijakan dan evaluasi kebijakan. Implementasi kebijakan mengandung logika top-down. Maksud logika top-down adalah menurunkan atau menafsirkan alternatif yang masih abstrak atau makro menjadi alternatif yang bersifat konkret atau mikro. 
Tahapan implementasi kebijakan merupakan tahapan yang sangat penting dalam proses kebijakan. Artinya, implementasi kebijakan menentukan keberhasilan suatu proses kebijakan yang tujuan serta dampaknya dapat dihasilkan. Pentingnya implementasi kebijakan ditegaskan oleh pendapat Udoji (dalam Wahab, 2005:59): "The execution of policies is as important if not more important than policy making. Policy will remain dreams or blue prints jackets unless they are implemented." Hal serupa juga dikemukakan Islamy (2003) bahwa implementasi kebijakan adalah proses mewujudkan program sehingga memperlihatkan hasilnya. Pelaksanaan kebijakan tersebut dapat diartikan sebagai penyediaan sarana untuk melaksanakan sesuatu (to private the means for carrying out) sehingga menimbulkan dampak atau akibat terhadap sesuatu (to give practical effect to).

Pelaksanaan atau implementasi kebijakan membutuhkan persiapan yang matang, karena akan berhadapan dengan publik yang pada umumnya bersifat heterogen. Pendekatan yang digunakan untuk implementasi kebijakan menurut Edwards III (2008: 9) sebagai berikut:

"In our approach to study of policy implementation, we begin in the abstract and ask : what are praconditions for succesful policy implementation? what are the primary obstacles to successful policy implementation ? in the next four chapters we shall attempt to answer these important quetion by considering four critical factor or variabel in implementing public policy: communication, resources, disposition or attitudes and bureaucratis structure."

Selanjutnya, secara teoretis implementasi kebijakan publik memiliki dua pemilihan jenis teknik atau model. Pertama adalah implementasi kebijakan yang berpola "dari atas ke bawah" (topbuttomer) versus dari "bawah ke atas" (bottom-topper). Kedua, pemilihan implementasi yang berpola paksa (command-and-control) dan mekanisme pasar (economic incentive). Model-model implementasi kebijakan dapat dipetakan pada gambar berikut.

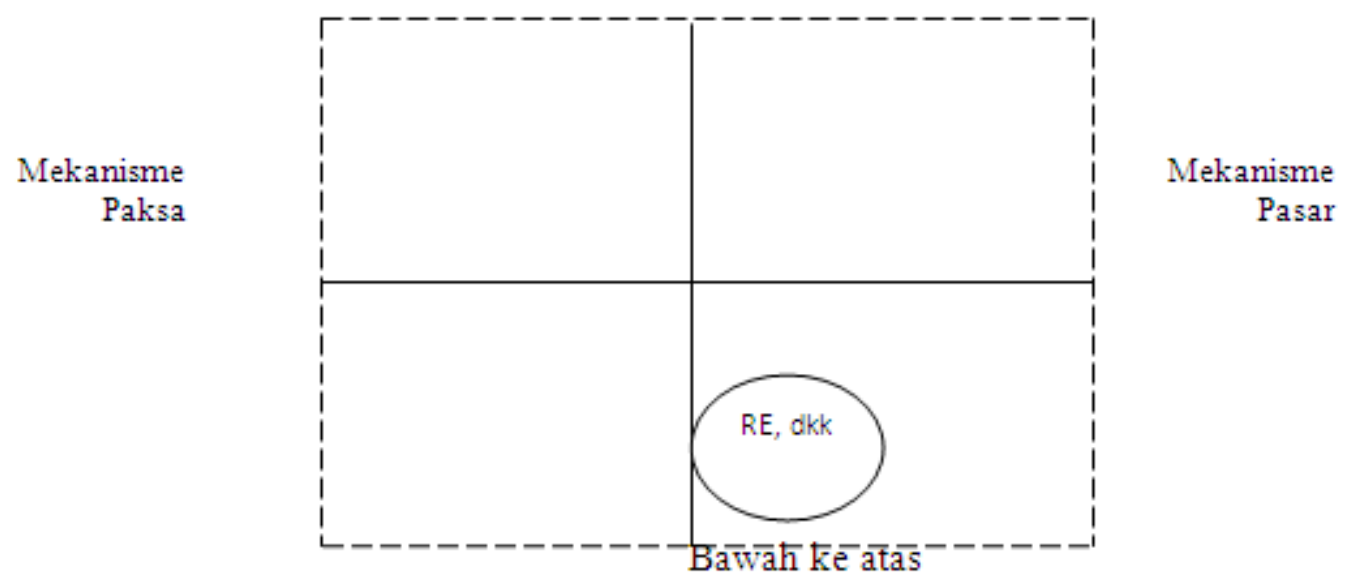

Gambar 1 Pemetaan Model Implementasi Kebijakan Publik Atas ke Bawah

(Sumber: Nugroho, 2008:177)

Model yang paling klasik adalah model yang dikenal sebagai model proses atau alur Smith. Dalam model ini, Smith beranggapan bahwa dalam proses implementasi terdapat empat variabel yang saling berkaitan, saling memengaruhi dan berinterkasi secara timbal balik, dan merupakan satu kesatuan. Akibatnya, terjadi ketegangan (tensions) yang bisa menyebabkan timbulnya protes atau aksi fisik yang menghendaki penegakan institusi-institusi baru untuk mewujudkan sasaran kebijakan tersebut (Tachjan, 2006).

Mazmanian dan Sabatier (2003:2) merumuskan model implementasi yang dikenal sebagai $a$ Framework for Implementation Analysis. Ada tiga variabel yang memengaruhi tercapainya tujuantujuan formal pada implementasi kebijakan, yaitu: (1) mudah tidaknya masalah yang akan 
digarap/dikendalikan; (2) kemampuan keputusan kebijakan untuk menstrukturkan secara tepat proses implementasi; (3) variabel di luar kebijakan yang memengaruhi proses implementasi. Model yang dikembangkan Hogwood dan Gunn (2004) yang dikenal sebagai top down approach, antara lain: (1) kondisi eksternal yang dihadapi oleh badan/instansi pelaksana tidak akan menimbulkan gangguan /kendala yang serius; (2) untuk pelaksanaan program tersedia waktu dan sumber-sumber yang cukup memadai; (3) perpaduan sumber-sumber yang diperlukan benar-benar tersedia; (4) kebijaksanaan yang akan diimplentasikan didasari oleh suatu hubungan kausalitas yang andal; (5) hubungan kausalitas bersifat langsung dan hanya sedikit mata rantai penghubungnya; (6) hubungan saling ketergantungan harus kecil; (7) tugas-tugas diperinci dan ditempatkan dalam urutan yang tepat; (8) komunikasi dan koordinasi yang sempurna, dan (9) pihak-pihak yang memiliki wewenang kekuasaan dapat menuntut dan mendapatkan kepatuhan yang sempurna. Sementara model yang dikembangkan Van Meter dan Van Horn (1975) disebut sebagai a Model of the Policy Implementation Process. Model tersebut menggunakan unsur-unsur: ukuran dan tujuan kebijaksanaan, sumber-sumber kebijaksanaan, ciri-ciri atau sifat badan/instansi pelaksana, komunikasi antarorganisasi terkait dan kegiatan-kegiatan pelaksanaan, sikap para pelaksana, dan lingkungan ekonomi, sosial, dan politik.

Salah satu aktivitas implementasi kebijakan dikemukakan oleh Jones (2004:67). Ia mengartikan implementasi sebagai "getting the job done and doing it". Lebih lanjut, Jones menyatakan bahwa dalam implementasi kebijakan terdapat tiga hal yang berperan, yaitu: (1) Organization: the establishment of rearrangement resources, units, using methods for putting policy into effect; (2) Interpretation: the translation of language (often contained in a statue) into acceptable and feasible plans and directives; (3) Application: the routine provision of service, payments, or other agree upon objectives or instruments. Implementasi kebijakan publik, apapun bentuknya, perlu dipersiapkan dengan matang sehingga dapat menimbulkan dampak positif yang lebih besar bagi publik. Oleh karena itu, bagi administrator publik dan organisasi, interpretasi dan aplikasi dalam implementasi kebijakan harus dilihat secara cermat dan bijaksana dalam kualitas pelayanan publik.

\section{METODE PENELITIAN}

Penelitian ini dilakukan melalui teknik observasi dan wawancara. Data yang dikumpulan terdiri dari data primer, yaitu dari informan dan observasi, serta data sekunder di lapangan. Untuk itu desain penelitian ini menggunakan metode kualitatif. Metode penelitian ini dipilih dan dianggap tepat karena metode kualitatif relevan dan cocok dengan masalah penelitian yang diajukan melalui interpretasi proses dan makna.

Sumber data ini terbagi menjadi dua jenis sumber data yaitu sumber data primer dan sekunder. Data primer merupakan data yang diperoleh secara langsung melalui observasi di lapangan dan wawancara dengan informan. Data sekunder yang akan dijaring adalah melalui studi dokumentasi, yaitu data yang diperoleh melalui dokumentasi yang relevan dengan penelitian ini. Dalam data primer, informan yang dipilih adalah pejabat dilingkungan LPSE Provinsi Jawa Barat, yang meliputi: Koordinator LPSE, dan Ketua Tim Teknologi Informasi dan Komunikasi LPSE. Di samping itu juga dilakukan wawancara kepada salah satu pengurus Bandung Institute of Governance Studies (BIGS).

Lebih lanjut, proses pengumpulan data pada penelitian ini disesuaikan dengan jenis penelitian. Data yang dihimpun dalam penelitian ini, yaitu berupa kata-kata, tindakan, dokumen, situasi, dan peristiwa yang dapat diobservasi. Sumber data yang dimaksud adalah kata-kata diperoleh secara langsung atau tidak langsung melalui observasi dan wawancara dan dokumen berupa catatan kegiatan yang tersimpan dalam dokumentasi. 
Pengujian keabsahan data dalam penelitian ini didasarkan atas kriteria tertentu yaitu derajat kepercayaan dan kebenaran data (credibility) yang diperoleh dari para informan yang langsung terlibat dalam implementasi kebijakan Layanan LPSE pengadaan kendaraan dinas di Pemerintah Provinsi Jawa Barat, kebenaran (correctness) suatu deskripsi, kesimpulan, dan penjelasan (explanation) yang dapat diketahui dari kesesuaian dengan peraturan perundangan serta naskah/dokumen penting lainnya.

Kebenaran hasil penelitian akan dinilai oleh orang lain dan dapat diuji dalam berbagai situasi yang lain, analisis terdiri dari tiga alur kegiatan yang terjadi secara Bersamaan. Pertama, reduksi data, merupakan bagian dari analisis yang diartikan sebagai proses pemilihan, pemusatan perhatian pada penyederhanaan, pengabstrakan dan transformasi data kasar yang muncul dari catatan tertulis di lapangan. Kegiatan dalam tahapan reduksi adalah bentuk analisis yang menajamkan pembuatan penggolongan, mengarahkan, membuang yang tidak perlu dan mengorganisasi data sehingga dapat ditarik simpulan final dan diverifikasi. Kedua, penyajian data, merupakan sekumpulan informasi yang tersusun dan memberi kemungkinan adanya penarikan simpulan dan pengambilan tindakan. Dengan melihat penyajian data, dapat dipahami yang sedang terjadi dan yang harus dilakukan. Data disajikan dalam bentuk matriks, networks, charts atau grafik untuk memberikan gambaran secara menyeluruh. Ketiga, penarikan kesimpulan atau verifikasi, merupakan tahapan peneliti berusaha untuk mencari makna dari data yang dikumpulkan. Pola, tema, hubungan, dan persamaan dicari dan lalu dicoba untuk disimpulkan. Kesimpulan yang pada mulanya sangat tentatif, kabur, dan diragukan, dengan bertambahnya data, kesimpulan itu lebih akurat. Jadi kesimpulan harus segera diverifikasi. Analisis yang terdiri dari tiga alur kegiatan yaitu reduksi data, penyajian data, dan penarikan kesimpulan terjadi secara bersamaan, saling berhubungan, dan berlangsung terus-menerus selama penelitian dilakukan.

Uji keabsahan penelitian bertujuan untuk memberi jaminan kepercayaan dan kebenaran hasil penelitian, meliputi: standar kredibilitas yang digunakan untuk mencapai tingkat kepercayaan temuan dengan membandingkan hasil tersebut dengan kenyataan ganda yang diteliti, ketekunan pengamatan, menemukan unsur-unsur dengan ciri-ciri situasi yang relavan dengan persoalan, selanjutnya memusatkan diri pada hal tersebut secara lebih rinci dan teliti. Uji keabsahan data pada penelitian ini akan dilakukan melalui triangulasi yaitu teknik pengujian keabsahan data dilakukan dengan memeriksa kebenaran data yang diperoleh pada pihak-pihak lain yang dapat dipercaya.

\section{HASIL DAN PEMBAHASAN}

Pengadaan kendaraan dinas di lingkungan pemerintah diperlukan untuk menunjang dan mempermudah segala urusan atau pekerjaan yang berkaitan dengan pelayanan pemerintah kepada masyarakat. Karena peruntukannya yang bersifat publik dan untuk operasional pemerintah, kendaraan ini diadakan atau dibeli dari anggaran belanja negara atau daerah yang sumber keuangannya berasal dari pajak masyarakat. Sering kali pengadaan kendaraan dinas dibeli dalam jumlah yang tidak sedikit dan karenanya pengadaan ini sering kali menggunakan anggaran yang tidak sedikit pula. Bagi beberapa oknum pejabat dan pengusaha pengadaan kendaraan dinas terkadang dijadikan sebagai momen yang tepat untuk memperoleh keuntungan pibadi, tetapi merugikan keuangan negara.

Meskipun ketentuan pengadaan kendaraan dinas dilakukan melalui sistem tender atau lelang untuk menghindari terjadinya praktik korupsi antara oknum pejabat dan pengusaha, sebelum diberlakukannya kebijakan pengadaan barang yang berbasis pada Layanan Pengadaan Secara Elektronik (LPSE), ditemukan berbagai macam praktik korupsi dalam pengadaan kendaraan dinas di lingkungan pemerintahan. Hal tersebut dikarenakan kebijakan pengadaan barang dan jasa sebelum diberlakukannya kebijakan LPSE masih menerapkan sistem lelang atau tender konvensional. Tender konvensional yaitu proses tender dan lelang mulai dari awal pemerintah mengeluarkan informasi 
tentang adanya pengadaan barang sampai dengan pengumuman keputusan pemenang dilakukan secara tatap muka dan kontak fisik.

Layanan Pengadaan Secara Elektronik (LPSE) merupakan hasil dari kebijakan pemerintah yang memanfaatkan teknologi informasi dan komunikasi. Dengan diimplementasikannya kebijakan pengadaan barang melalui sistem LPSE kendala proses komunikasi, jarak, waktu, dan juga biaya dalam pengadaan barang dan jasa dapat direduksi secara signifikan. Tatap muka dan kontak secara fisik antara panitia pengadaan dan penyedia (vendor) - yang sering menjadi penyebab terjadinya intransparansi dan timbulnya peluang bagi terjadinya KKN dalam pengadaan barang dan jasa pemerintah-juga tidak diperlukan lagi. Dengan sistem LPSE, sejak dari pendaftaran, penawaran, penyanggahan, sampai dengan penentuan pemenang, dilakukan secara online dengan hanya membuka situs lembaga pemerintah yang dituju. Hal ini mempunyai arti penting, karena selama ini sebagian besar kasus korupsi di kalangan aparat pemerintah di Indonesia, berasal dari kolusi atau penyalahgunaan wewenang dalam pengadaan barang dan jasa.

Kebijakan LPSE di Provinsi Jawa Barat diimplementasikan pada Juli 2008 yaitu pada masa kepemimpinan Gubernur Ahmad Heryawan. Implementasi kebijakan LPSE juga ditandai dengan adanya peranan yang cukup berarti dari berbagai organisasi masyarakat sipil (civil society organization) yang secara aktif ikut dalam proses persiapan serta advokasi Rencana Aksi Daerah Untuk Pemberantasan Korupsi (RA-DPK). Dalam rencana ini penerapan LPSE dimasukkan sebagai salah satu komponen utama. Rencana Aksi Daerah Untuk Pemberantasan Korupsi ini kemudian menjadi kebijakan resmi Pemerintah Provinsi Jawa Barat yang ditetapkan melalui sebuah peraturan gubernur.

Penerapan LPSE di Provinsi Jawa Barat, oleh gubernur, dijadikan sebagai salah satu agenda prioritas kegiatan Pemerintah Provinsi Jawa Barat pada Triwulan III 2008. LPSE menyelenggarakan pengadaan barang dan jasa pemerintah secara elektronik. Di Provinsi Jawa Barat perusahaan yang ingin mengikuti proses pengadaan barang dan jasa dapat terlebih dahulu mendaftar sebagai penyedia barang/jasa yang dilakukan secara online. Mekanisme sederhana proses pengadaan barang dan jasa melalui LPSE dapat dilihat dari gambar berikut.

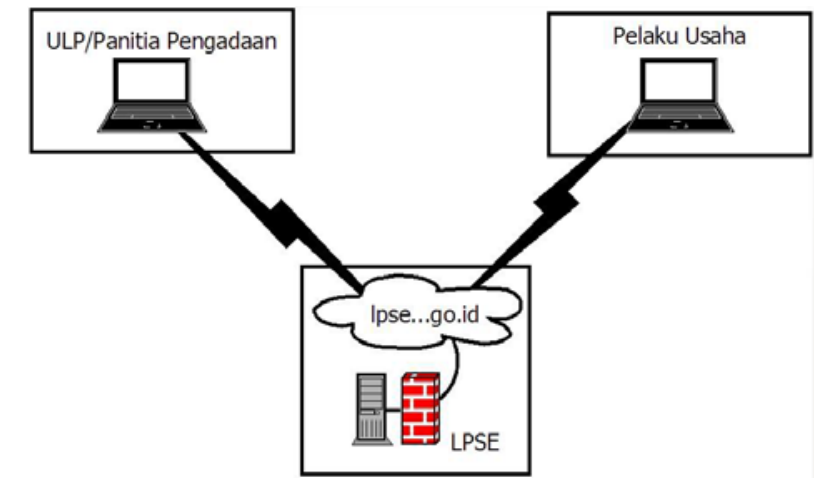

Gambar 2 Layanan Pengadaan Secara Elektronik (LPSE)

(Sumber: LGSP, 2011)

Sejak diluncurkan 1 Juli 2008 oleh Gubernur Jawa Barat, Ahmad Heryawan, Layanan Pengadaan Barang atau Jasa Secara Elektronik (LPSE) di Jawa Barat menunjukan prestasi gemilang. Gebrakan dengan mewajibkan semua lelang barang atau jasa melalui LPSE menuai hasil dan pengakuan nasional. Seperti meraih juara umum LPSE Tingkat Nasional tahun 2010, merupakan wujud pengakuan masyarakat atas keberhasilan Pemerintah Provinsi Jawa Barat dalam mengelola LPSE. Manfaat LPSE menurut Pemerintah Provinsi Jawa Barat tidak hanya percepatan penyerapan 
anggaran, tetapi juga efisiensi. Khusus untuk lingkup Organsiasi Perangkat Daerah (OPD) Provinsi Jawa Barat efisiensi anggaran pada 2010 mencapai Rp 210 miliar atau 16,18 persen. Sedangkan untuk keseluruhan lelang yang melalui LPSE Jabar nilai efisiensinya mencapai Rp 263 miliar atau 14,16 persen. Komisi Pemberantasan Korupsi (KPK) menilai pelaksanaan LPSE di Jawa Barat baik dan berhasil. Berdasarkan pantauan KPK pada 2010, pengaduan seputar pengadaan barang/jasa menurun drastis.

Pada 2011 peningkatan efisiensi anggaran terlihat semakin sangat signifikan terhadap jumlah paket yang dilelang melalui LPSE. Jumlahnya mencapai 3.224 paket dengan nilai menembus angka Rp 4 triliun lebih. Menurut Kepala Balai LPSE: "Baik paket maupun nilai efisiensinya meningkat 100 persen dibandingkan pada kurun yang sama tahun 2010 lalu sebanyak 1.562 paket. Ini merupakan capaian prestasi yang harus terus dipertahankan sesuai arahan Gubernur Jawa Barat yang mendorong kinerja LPSE dalam kerangka akuntabilitas dan efisiensi anggaran.” Pengadaan kendaraan dinas bagi keperluan operasional Pemerintah Provinsi Jawa Barat juga harus melalui mekanisme pengadaan barang secara online, yakni melalui LPSE. Pemerintah Provinsi Jawa Barat berkomitmen untuk menciptakan sebuah pemerintah yang baik dan bersih (clean and good government). Karenanya, segala bentuk kegiatan pengadaan barang, termasuk kendaraan dinas, harus dilakukan secara terbuka dan transparan.

Implementasi kebijakan LPSE dalam pengadaan kendaraan dinas dinilai oleh Pemerintah Provinsi Jawa Barat telah memberikan dampak yang cukup positif bagi kondisi keuangan daerah. Bentuk nyata dari baiknya kondisi keuangan daerah di Provinsi Jawa Barat terlihat dari adanya penilaian Badan Pemeriksa Keuangan (BPK) bahwa Laporan Keuangan Pemerintah Daerah (LKPD) Pemerintah Provinsi Jawa Barat Tahun Anggaran 2011 meraih opini wajar tanpa pengecualian (Sumber: BPK, 2012). Komitmen untuk menciptakan pemerintahan yang bersih dan transparan melalui penerapan sistem LPSE, juga telah membawa Pemerintah Provinsi Jawa Barat sebagai satusatunya pemerintah provinsi yang berhasil meraih penghargaan nasional sebagai "Badan Publik Terbaik Dalam Keterbukaan Informasi Publik” (Pemerintah Provinsi Jawa Barat, 2012). Keterbukaan informasi publik dimaksud adalah masyarakat dapat mengetahui tentang proses lelang atau pengadaan barang, termasuk kendaraan dinas, mulai dari awal hingga akhir, baik yang meliputi jenis, merek, spesifikasi mesin dan harga kendaraan.

Pengadaan barang melalui LPSE di desain sedemikian rupa untuk dapat diakses oleh publik secara terbuka, yaitu dengan menggunakan jaringan Internet. Adapun Network Design LPSE digambarkan sebagai berikut.

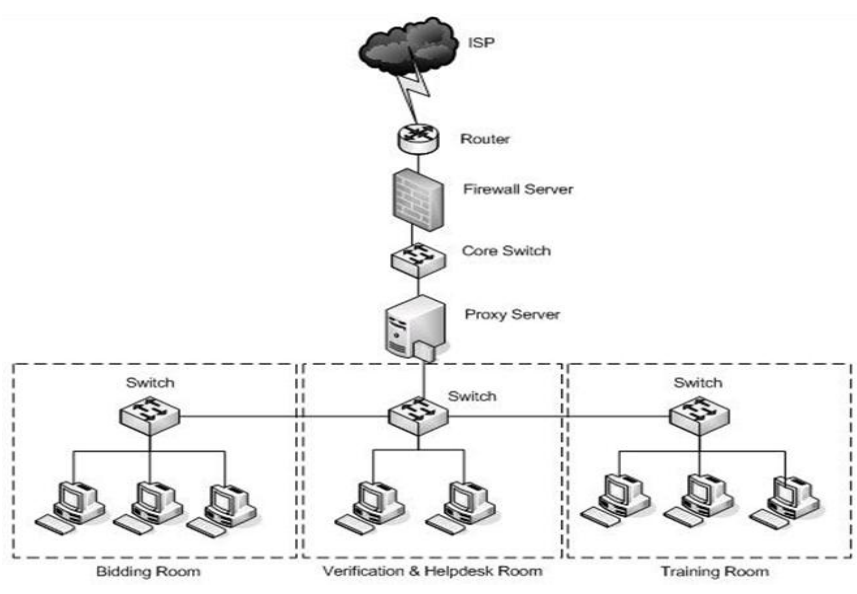

Gambar 3 Network Design LPSE

(Sumber: LGSP, 2011) 
Keberhasilan implementasi kebijakan Layanan Pengadaan Secara Elektronik (LPSE) dalam hal pengadaan kendaraan dinas di lingkungan Pemerintah Provinsi Jawa Barat, dapat dianalisis dari tiga hal yang berperan dalam implementasi kebijakan (Jones, 2004:67), yaitu: (1) Organization: the establishment of rearrangement resources, units, using methods for putting policy into effect; (2) Interpretation; the translation of language (often contained in a statue) into acceptable and feasible plans and directives; (3) Application: the routine provision of service, payments, or other agree upon objectives or instruments. Terkait dengan organisasi, bahwa organisasi diperlukan agar pekerjaan dapat dilaksanakan. Dalam pemerintahan organisasi ini berwujud sebagai birokrasi. Tujuan awal dari adanya organisasi adalah menjalankan program-program yang dirancang sebelumnya, dalam konteks penelitian ini adalah menjalankan kebijakan LPSE. Tanpa adanya organisasi yang meliputi sumber daya, unit-unit serta metode untuk menjadikan program dapat berjalan maka pelaksanaan kebijakan LPSE dalam pengadaan barang secara elektronik di Pemerintah Provinsi Jawa Barat tidak akan berjalan.

Dukungan aparat birokrasi terhadap implementasi kebijakan LPSE terlihat sangat kuat. Hal ini sebagaimana diungkapkan oleh Kepala Balai LPSE dan Kepala Biro Kepegawaian Pemerintah Provinsi Jawa Barat. Selain adanya dukungan yang kuat, ketersediaan sumber daya manusia yang andal dan profesional juga diperlukan. Mengingat sistem ini dilakukan secara online, diperlukan SDM yang memahami tentang jaringan sistem Internet.

Interpretasi merupakan cara pelaksana untuk menafsirkan agar program menjadi rencana, pengarahan yang tepat, dapat diterima dan dilaksanakan. Pemerintah Jawa Barat, melalui gubernur, mengetahui betul apa dan bagaimana tujuan akhir itu harus diwujudkan atau direalisasikan. Karenanya dalam tahapan interpretasi, Pemerintah Provinsi Jawa Barat menjabarkan kebijakan yang masih relatif bersifat abstrak ke dalam kebijakan yang lebih bersifat teknis operasional. Kebijakan umum dijabarkan ke dalam kebijakan manajerial dan kebijakan manajerial akan dijabarkan ke dalam kebijakan teknis operasional. Hal tersebut diikuti dengan kegiatan mengomunikasikan kebijakan (sosialisasi) agar seluruh anggota organisasi dan masyarakat mengetahui dan memahami apa yang menjadi arah, tujuan, dan sasaran (kelompok sasaran) kebijakan.

Aplikasi menurut Jones (2004) sebagai aktivitas penyediaan pelayanan rutin, pembayaran atau lainnya yang sesuai dengan tujuan kebijakan yang ada. Jadi aplikasi adalah tahap penerapan rencana proses implementasi kebijakan ke dalam realitas. Tahap aplikasi merupakan perwujudan dari pelaksanaan masing-masing kegiatan dalam tahapan yang telah disebutkan sebelumnya. LPSE yang berawal dari lahirnya sebuah kebijakan tidak akan dapat mendorong lahirnya pemerintahan yang bersih jika tidak diaplikasikan dalam tindakan nyata. Keberhasilan Pemerintah Provinsi Jawa Barat dalam menciptakan pemerintahan yang baik dan bersih tidak dapat terlepas dari adanya pengaplikasian kebijakan LPSE di Provinsi Jawa Barat.

\section{SIMPULAN}

Implementasi kebijakan Layanan Pengadaan Secara Elektronik (LPSE) yang diterapkan di lingkungan Pemerintah Provinsi Jawa Barat disimpulkan dapat berjalan dengan baik. Penerapan sistem LPSE dalam pengadaan barang dan jasa, khususnya dalam pengadaan kendaraan dinas, dapat meminimalkan terjadinya potensi korupsi anggaran. Hal ini karena sejak dari pendaftaran, penawaran, penyanggahan sampai dengan penentuan pemenang dilakukan secara online dan tidak dilakukan secara tatap muka atau kontak secara fisik. Sistem LPSE membuat proses pengadaan barang dilakukan secara transparan dan terbuka. Hal ini sangat mendukung semangat reformasi politik di Indonesia yaitu terwujudnya good governance. Keberhasilan implementasi kebijakan LPSE di Pemerintah Provinsi Jawa Barat didukung oleh adanya ketersediaan organisasi birokrasi yang meliputi dukungan 
pegawai dan ketersediaan sumber daya manusia yang andal dan profesional; kemampuan Pemerintah Provinsi Jawa Barat menjabarkan kebijakan yang masih relatif bersifat abstrak kedalam kebijakan yang lebih bersifat teknis operasional, sehingga dapat mudah diinterpretasikan oleh pegawai; dan kemampuan pemerintah menerapkan rencana proses implementasi kebijakan dalam realitas.

\section{DAFTAR PUSTAKA}

Anderson, J. E. (2010). Public Policy Making. Chicago: Holt, Rinehart and Winston.

Buse, K., Mays. N., Walt, G. (2005). Making Health Policy. Maidenhead: Open University Press.

Edwards III, G. C. (2008). Implementing Public Policy. 8th Revision. Washington: Congressional Quarterly Press.

Hogwood, B. W., and Gunn, L. A. (2004). Policy Analysis for The Real World. New York: Oxford University Press.

Islamy, M. I. (2003). Prinsip prinsip Perumusan Kebijakan Negara. Jakarta: Bumi Aksara.

Jones, C. O. (2004). Pengantar kebijakan Publik (terjemahan). Jakarta: Raja Grafindo Persada.

Kompas. (2009). Kinerja SBY-JK. Diakses Januari 2013 dari http://cetak.kompas.com/read/xml/200...kinerja.sby-jk.

Local Governance Support Program (LGSP). (2011). Pratik-praktik yang Baik di Unit Pelayanan Pengadaan Barang dan Jasa secara Elektronik (LPSE) di Jawa Barat. Bandung: LGSP, Lembaga Kebijakan Pengadaan Barang/Jasa Pemerintah (LKPP), Pemerintah Provinsi Jawa Barat, dan USAID.

Mazmanian, D.A., dan Sabatier, P. A. (2003). Implementation and Public Policy. London: Scott, Forestman and Company.

Nugroho, R. (2008). Kebijakan Publik Formulasi, Implementasi, dan Evaluasi. Jakarta: Elex Media Komputindo.

Pemerintah Provinsi Jawa Barat (2012). Gubernur Terima Anugrah Terbaik Keterbukaan Informasi Publik. Diakses Januari 2013 dari http://www.jabarprov.go.id/index.php/subMenu/informasi/berita_foto/detailberitafoto/505.

Tachjan. (2006). Implementasi Kebijakan Publik. Bandung: Lemlit Unpad.

Tempo (2009). Danny Setiawan Divonis Empat Tahun Penjara. Diakses Januari 2013 dari http://www.tempo.co/read/news/2009/06/30/063184534/Danny-Setiawan-Divonis-EmpatTahun-Penjara.

Transparency International (2011). Corruption Perceptions Index. Diakses Januari 2013 dari http://www.transparency.org/cpi2011/results.

. (2012). Poverty and Development. Diakses Januari 2013 dari http://www.transparency.org/topic/detail/poverty_and_development. 
Van Meter, D. \& Van Horn, C. 2004. The policy implementation process: A conceptual framework. Administration \& Society.

Wahab, S. (2005). Analisis Kebijakasanaan: Dari formulasi ke Implementasi. Kebijaksanaan Negara. Jakarta: Bumi aksara.

Walt, G., J. Shiffman, H. Schneider, S. Murray, R. Brugha, and L. Gilson. (2008). Doing' Health Policy Analysis: Methodological and Conceptual Reflections and Challenges. Health Policy and Planning. Vol 23(5): 308-317.

Winarno, B. (2005). Teori \& Proses Kebijakan Publik. Yogyakarta: Media Pressindo. 